\title{
Sustainable development unsustainable
}

Environmentalists tempted to Ignore Wilfred Beckerman's latest book had better think again; there is no better way of 'knowing your enemy', and no more mordant enemy.

YET another book review preceded by the disclaimer that the author is a friend or, in this case, worse - an ally! The author is the Balliol (Oxford) economist Wilfred Beckerman. The title, an obvious parody of that of E.F. ("Fritz") Schumacher's Small is Beautiful (Blond, 1973), is Small is Stupid (Duckworth, 1995). But Beckerman, whose professional field of expertise is the national accounts of nation-states such as Britain, has not on this occasion written an economic textbook, but a tract. That, in a sense, is what Schumacher did, but in gentler language.

The circumstances of my alliance with Beckerman are these. In 1971, he was a member of the British Royal Commission (standing committee) on Environmental Pollution and in that role was bombarded with photocopies of articles appearing in the press at large, Nature included, on environmental matters. (The commission's otherwise excellent secretariat seems to pay no attention to copyright law.) At some stage, Beckerman wrote to say that some article in Nature seemed to him to take a level-headed view of the economics of pollution, so when it came to debating an environmental topic at the Oxford Union, I recruited him as my second. (He was excellent, but we lost.)

It was there I first heard his joke (retold in this book) about the element called 'Beckermonium', allegedly named after his grandfather who had failed to discover it. Has the world been the worse for his neglect is the rhetorical punchline, an oblique comment on the assertion that the industrial economies of the world are quickly using up the minerals on which they apparently depend.

The joke apart, environmentalists will not find the book a comfortable read. The subtitle, "Blowing the whistle on the Greens", is a sufficient warning. And Beckerman does enjoy making fun of false past predictions of catastrophe; the table in which he compares the reserves of metals such as copper and lead quoted in The Limits to Growth (1972) with the corresponding values for 1989 is headed, with studied inelegance, "How we used up all the resources we had and still finished up with more than we started with".

To take the metal lead as an example, consumption between 1970 and 1989 amounted to 99 million tonnes, rather more than the 91 million metric tonnes of reserves supposed to exist in 1970 , yet by 1989 the known reserves of lead had actu- ally increased, to 125 million tonnes. There, Beckerman might have said, is a widow's cruse for you! This and similar arguments point him to the conclusion that there must be "major flaws" in the argument that the Earth's resources are finite; surprisingly, for an economist, he does not suggest that what matters in the real world is the distribution of reserves with price (or extraction cost).

But environmentalists rather than those already converted to Beckerman's view are the ones who should read his book. Its purpose is to take apart the nowfamiliar notions of "sustainable development" and "precautionary principle". The former appears in the Brundtland Report (named in 1987 after its woman chairman, the prime minister of Norway, and entitled Our Common Future). For on the principle that one should know one's enemy, environmentalists need to know why some say that "sustainable development" is meaningless in the strict sense that it is empty of operational meaning. "The Emperor of Sustainable Development has no clothes", says Beckerman.

$\mathrm{He}$ is surely right. It is not only a matter of definition, although the definitions matter. Brundtland's injunction, for example, is that sustainable development must meet "the needs of present generations without compromising the ability of future generations to meet their own needs". It is not a frivolous question to ask how it can be possible with any certainty to know what future needs will be.

In the absence of more information, it is reasonable to suppose that future needs and present needs will be identical, but the logical consequence is that it would be improper of the present generation to make any use of a nonrenewable resource, say lead. To do so would mean that future generations would be less free than we are to mine lead, but on the assumption that the goal of sustainable development is itself sustainable across the generations, future generations would also be interdicted (by Brundtland) from using lead. Nonrenewable resources would be untouchable unless one generation could persuade itself that its successors will have less need of lead than we have.

There are many contrary examples in economic history. In South Wales in the 1920 s, for example, the output of coal from the coalmines amounted to 250 million tons a year, of which 100 million tons were exported from Welsh ports to coun- tries outside Britain. Evidently the notion of sustainable development had not caught on. Even if the extraction of the domestic demand for coal (150 million tons a year) could be justified on the grounds that there seemed to be plenty more where that came from, physically exporting 100 million tons a year of it must surely have 'compromised' the ability of future (that is, present) generations to 'meet their own needs'.

The snag, of course, is that coal consumption has slumped. Deep-mined coal production from the region is now less than 1 per cent of what it was 70 years ago. So in what way would it have benefited South Wales, either in the 1920s or now, if it had been resolved not to extract coal in excess of local demand? The region would have been less prosperous than it was and thus less able to build the excellent school system that was, for many years, its hallmark. Now there is no coalmining industry worth speaking of.

Beckerman, in his book, argues that the sustainability engineers have been watering down sustainability ever since Brundtland appeared. He makes easy game of his compatriot-economist David Pearce, who most recently subscribes to a definition in terms of wellbeing (which must not deteriorate over the generations), but which allows the substitution of man-made for 'natural' capital on the surface of the Earth. Is not that just another way of saying the 'welfare' (of which the predominant component is gross national product) is all that matters?

The 'precautionary principle', the doctrine that one should act now in case things go wrong later, unravels in much the same way, but Beckerman the economist is more obviously in charge. The extra cost of acting too soon is never calculated accurately. And putting the precautionary principle into effect often destroys the evidence of its necessity.

In short, Beckerman has written a thoughtful book as well as an entertaining one. Environmentalists will not be too badly hurt by the jibes. But Beckerman is probably wrong in putting global warming in the same bag as the other green excesses. $\mathrm{He}$ is right, of course, to insist that the cost of delaying action would be less than the global warmers say, but the interval should be used as a time of preparation to take action. That, luckily, is what this month's meeting in Berlin is all about.

John Maddox 